\title{
COOKED RICE INNOVATION TO INCREASE THE TOURISM ATTRACTION OF PINDUL CAVE
}

\author{
MARWANTI* \\ Universitas Negeri Yogyakarta, Department of Culinary Education, Indonesia, e-mail: marwanti@uny.ac.id \\ Siti HAMIDAH \\ Universitas Negeri Yogyakarta, Department of Culinary Education, Indonesia, e-mail: siti_hamidah@uny.ac.id \\ Ezra Chica'al SANDYA \\ Universitas Negeri Yogyakarta, Department of Culinary Education, Indonesia, e-mail: ezrachicaal@uny.ac.i
}

\begin{abstract}
Citation: Marwanti, Hamidah, S., \& Sandya, E.C. (2020). COOKED RICE INNOVATION TO INCREASE THE TOURISM ATTRACTION OF PINDUL CAVE. GeoJournal of Tourism and Geosites, 34(1), 42-46. https://doi.org/10.30892/gtg.34106-617
\end{abstract}

\begin{abstract}
Food tourism has a vital role in sustainable tourism. However, there are still many local culinary products that have not been widely requested by tourists. This study aims to find a recipe for rice product innovation as one of the culinary icons in Pindul Cave, to find out people's acceptance of nasi pindul (pindul rice). This research uses a research and development approach from Borg and Gall, which is simplified into three steps. The first step, preliminarystudy to identify various rice recipes, then analyzed through FGD with expert judgment. The FGD produced three rice recipes that could be developed. Through expert opinion, one relevant recipe is chosen to be developed. The second step, development of the recipe chosen with the substitution of local ingredients namely cassava. The last step, testing the recipe with a sensory test and customer satisfaction test. The results of the study revealed that innovation in culinary products in Pindul Cave Tourism is Pindul Rice. Pindul rice is made from savory white rice mixed with grated cassava, wrapped in leaves and grilled, with a side dish of fried or roasted chicken side dish, supplemented with chili sauce and raw vegetables. Reasons for choosing cassava as a mixture in pindul rice arecassava as a local food that is easily obtained, cheap, easy to process; can improve the business and competitiveness of culinary businesses; and pindul rice has the potential to become a culinary icon of Pindul Cave tourism which have impact increase the selling price of cassava and finally improve the welfare of the surrounding community. It could be interpret form its research that pindul rice can be accepted and have a big potential to be liked by tourismbased on a sensory perspective.
\end{abstract}

Key words: culinary, tourism, innovation, food tourism

\section{INTRODUCTION}

The development of Goa Pindul (Pindul Cave) tourism, a tourist destination in the Special Province of Yogyakarta, Indonesia, has increased local economic activities. One of the benefits is providing opportunities and employment for the community by developing local culinary entrepreneurs. However, local food products do not yet have a clear market segment. Therefore, it is necessary to create culinary products. Zainal et al. (2010) explained that the demand for tourists for authentic flavors and culinary experiences had become a primary attraction. In practice, tourism objects seek to develop their unique identity and distinctiveness. This trend can be seen from most of the attractions that have made a pretty hard effort to promote their local culinary so that it becomes a cultural development activity that is its mainstay (Zainal et al., 2010). The development of rice-based culinary products in this research is based on menus that have been commonly served in Pindul Cave. However, the food menu does not show location characteristics. Rice served as in general, and the difference is only in the presentation of vegetables and side dishes that use traditional food menus that are still simple.

This is not in line with the increasingly critical demands of consumers about food. Soeroso and Susilo (2014), in their research results, explained that people who travel prefer to eat dinner outside the hotel to see the city $(90.67 \%)$ and enjoy local Indonesian specialties $(82.67 \%)$ (Figure 1). Consumers are accustomed to demanding special food menus, immortalized, and then uploaded on social media. Nelson (2016) culinary tourism, describes a trip that is motivated by the interest of tourists in finding out about the special food that is in that place. Some tourists argue that culinary tourism provides the primary motivation and is part of the hope that tourists can visit to enjoy culinary.

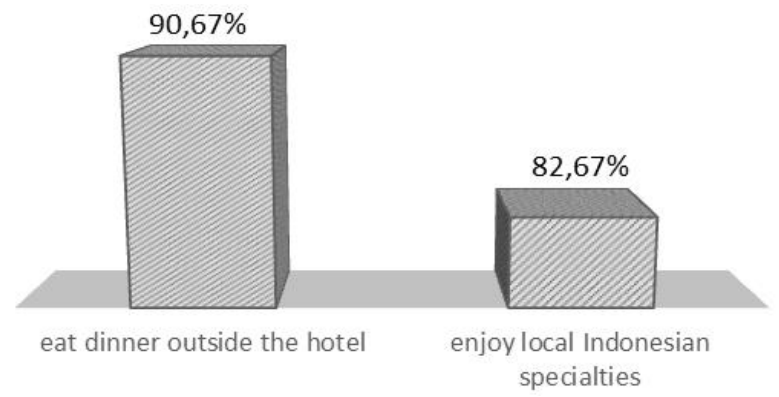

Figure 1. The prefer to eat dinner consumers (Source: Soeroso and Susilo, 2014)

According to Mirosa and Lawson (2012), despite the increase in local food and food-related behavior in general, the development of local food is currently minimal. Previous research has investigated that increasing food and domestic tourism is influenced by several perspectives, such as culture, environment, and others (Björk and Kauppinen-Räisänen, 2014). This opportunity makes the potential for the development of local culinary combined with the right processing techniques. Therefore, food providers are demanded to be creative and

\footnotetext{
${ }^{*}$ Corresponding author
} 
always innovate in serving their food menu. Karim et al. (2017) show the benefits of culinary imagery are very positive, and it is a challenge to develop these images in terms of promotion, information dissemination, education, and acceptance among consumers. The quality of food taste, sensory aspects of food, and the variety of food served are fundamental to creating attraction. In addition to the value of taste, health value is also an essential consideration for tourists to choose food (Kim and Eves, 2012). Local food is food that is produced and developed following the potential and resources of the region and local culture. Regional food diversity currently has great potential to be developed into a culinary business based on economic potential. The experience of feeling originality, novelty, and locality is an essential aspect of the food experience (Sthapit et al., 2017). Food experience for tourists is not a supportive experience but is the culmination of the experience (Mahfud et al., 2018; Mahfud et al., 2019; Zhang et al., 2019). The attention of residents and tourists shows an increasing interest in locally grown and produced food (Ritchie and Tung, 2011). Silkes et al. (2013) found that tourists' strong appreciation of the local food experience gave rise to its charm. The experience gained through local food enhances a strong impression of the destinations visited.

Gunung Kidul has local food potential, which is considered capable of increasing the economic value of the community. Gunung Kidul area, in general, has local food potential in the form of cassava, canna edulis, and other types of cassava (Natalia, 2015). The popularity of local food has grown substantially in the last decade (Bianchi, 2017), so that it hopes to foster creativity in new food products based on local ingredients. Cultivating creativity in food processing occurs through a continuous learning process. This means that self-awareness must be raised to the mastery of knowledge, skills, attitudes, or affective as the power to change, or grow human resources development. In this way, the food organizer will have the strength to develop a better food business, mastery of culinary work more professionally, and perseverance to succeed. The main motive for eating can be classified into three forms, namely culinary tourism, gastronomy, and nature. Food as a secondary motive is known as culinary tourism (Yusoff, 2019).

Things that can be used as a basis for consideration in developing culinary is the need to know how the tendency of consumer behavior towards food. Sam (2015), states that five main trends can influence consumer behavior towards food. The five trends are: 1) from massproduced to personalized. Generally, consumers want products that are processed by a small scale to ensure quality and to feel a closer relationship with the brand they choose, 2) better-for-you ingredients. Consumers will always increase their concern for the ingredients, 3) all things hot and spicy. The tastes of consumers towards food that tend to be tasty and spicy, 4) mix-and-match your favorite flavors. Consumers will look for exciting products, which are favored foods and have a mixture of flavors, 5) packaging drives the sensory experience. Another package from another, which provides a unique and powerful sensory experience (Choe and Kim, 2018).

An essential factor for the success of culinary activities or food products is one of them through recipes. The recipe gives careful and precise instructions on various matters, including composition and proportion of ingredients, how to treat the ingredients, techniques used, and work procedures used. The goal is so that people, in general, can do the same thing as desired recipes (Hamidah and Komariah, 2013). Mak et al. (2012), several things that determine the factors that influence consuming local food are cultural and religious factors, sociodemographic, motivation, personality, and experience. It is also recognized in several studies that food selection is influenced by cultural and religious background (halal food). The local food consumption model according to Kim et al. (2009) is divided into sub-factors; motivational factors (exciting experiences, escape from routine, health problems, learning knowledge, authentic experiences, togetherness, sensual attraction), demographic factors (sex, age, education), physiological factors. The value of taste or quality of local food, emotional value, and epistemic value has a positive effect on tourists for local food so that it will affect tourist destinations for culinary tourism (Choe and Kim, 2018). Of the many articles that have been published, research on rice development to support local tourism is still minimal. Research on this continues to be done to increase the amount of variety and quality of local food as a significant supporter of domestic tourism.

To maintain quality and produce foods that are relatively awake from time to time, required a standard recipe. Standard recipes will determine the standard of taste, appearance, portion, and other provisions. The function of a standard recipe is so that consumers get the same food state over time, quality, and satisfaction. The perception of food quality for consumers is a natural and healthy food processing process (Grunert and Aachmann, 2016). The purpose of developing this rice is to raise the image of local food so that it stands parallel to the staple food menu of the community. This effort also aims to develop products as culinary icons of the Pindul cave in the Special Province of Yogyakarta, Indonesia, which needs support from the tertiary institution as a co-partner.

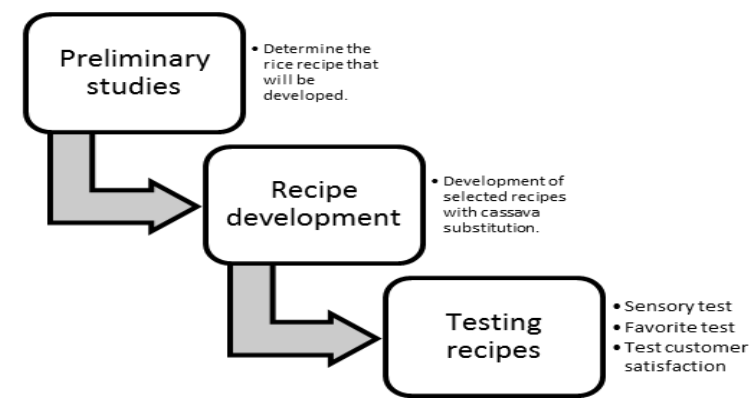

Figure 2. Cooked Rice development model as one of the Pindul cave tourism icons (Data source:Primary data)

\section{MATERIAL AND METHODS}

The research model of the development of a local food-based culinary business uses an Research and Development approach from Borg and Gall which was simplified by Sukmadinata (2008), this research was carried out in 3 steps (Figure 2): 1) a preliminary study by identifying various rice recipes. Then the recipe is analyzed through Forum Group Discussion activities with expert lecturers and resource persons. Output in the form of three rice recipes that can be developed. Through a literature study, food potential and advice from experts were chosen one relevant recipe for development, 2) Development of the recipe chosen with the substitution of local ingredients in the form of cassava. Cassava was selected because of its abundant potential, cheap, and easy to obtain. 3) Tes ting recipes with sensory tests and customer satisfaction tests. Test the results of development using experiments and analyzed through the Focus Group Discussion. The research output is a recipe for developing rice with the support of process technology and products.

There are several models that can be used as a Research and Development model. The Research and Development model whose main activities are taken from Richey and Klein, 2009. The basic assumption of development is because the research aims to obtain the recipe for the development of pindul rice with the support of process and product technology. Respondents are women who are members of the Family Welfare Empowerment group which is part of the Pindul Cave management, catering lecturers, and managing the Pindul Cave tourism object. Focus Group Discussion was conducted three times guided by open instruments. The data obtained were semi-structured in the form of conclusions from the active participation of participants during the discussion. 


\section{RESULTS}

\section{Preliminary studies}

Through preliminary studies, the research team has identified rice recipes that will be used for development. The recipe collected was analyzed through the Focus Group Discussion (FGD) activity to find three relevant recipes to be developed. The FGD involved a research team, food lecturers, experts, and leaders in Pindul Cave. The three FGD recipe results are then analyzed again based on strengths, weaknesses, development opportunities, and expert advice based on consumer demand today. The FG results are in the form of a recipe that has been through an analysis process whose results indicate that the formula is indeed relevant to be developed and easily adapted by the community for their culinary business.

\section{Recipe Development}

The recipe selected was based on analysis, and FGD was developed by substituting local ingredients. The substitution material used is cassava. This selection is because cassava is easy to find and low prices. The development of this recipe also aims to find a new standard innovation rice recipe as a culinary icon of Goa Pindul tourism. This recipe is made with an excellent proportion and composition of ingredients. The hope is to become a standard recipe so that it can be easily adapted by local culinary entrepreneurs, raising the level of local food, and empowering local people.

\section{Pindul Rice Recipe Design}

The design of this recipe design aims to create a new standard recipe for Pindul Rice by using local raw materials. The results of this new recipe design there are several choices, namely a) Savory red rice mixed with grated cassava, wrapped in banana leaves and burned; b) Savory white rice mixed with grated cassava, wrapped in banana leaves and baked; c) Non-savory red rice mixed with grated cassava and filled with spicy anchovies, wrapped in banana leaves and baked d) Non-savory white rice mixed with grated cassava and filled with spicy anchovies, wrapped in banana leaves and baked. The composition of the boiled rice testing material can be seen in Table 1 .

Pindul Rice 1

Savory red rice mixed with grated

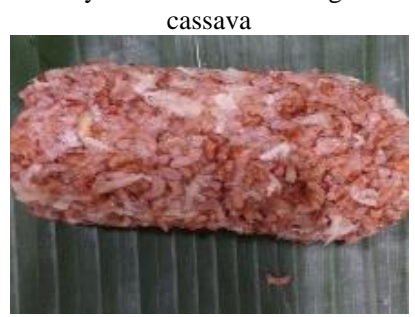

Table 1. The composition of Pindul rice innovation ingredients

Pindul Rice 2

Savory white rice mixed with grated cassava

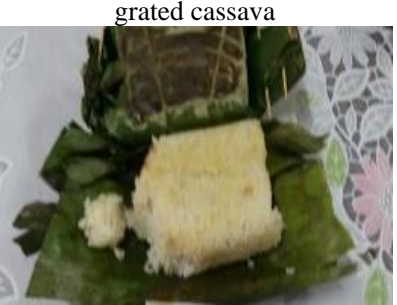

Pindul Rice 3

Non-savory red rice mixed with grated cassava and filled with spicy anchovies

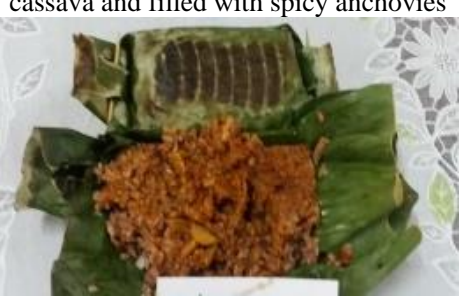

Pindul Rice 4

Non-savory white rice mixed with grated cassava and filled with spicy anchovies

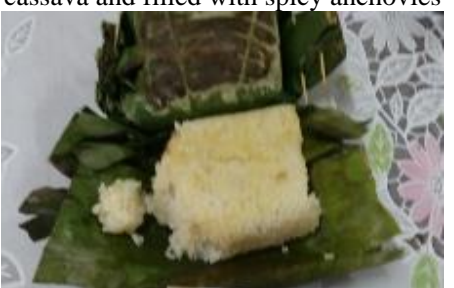

The results of the study showed that Pindul Rice 1 had a composition of ingredients in the form of brown rice, savory from coconut milk, and grated cassava. The advantages of brown rice are low sugar, but the texture is hard, the taste is less savory, and coconut milk is less pervasive. Grated cassava is very visible, so the color contrasts with rice. Not everyone likes brown rice. In the aspect of the portion is considered too large. Therefore, the first recipe Pindul rice is deemed to be inappropriate as the standard recipe for Pindul rice. Also, Pindul rice 2 has a composition of ingredients such as savory white rice and grated cassava. The advantage of the Pindul rice two recipes is the taste is almost the same as tasty rice in general. The color of white rice camouflages grated cassava color. The use of coconut milk gives a savory flavor. In the aspect of texture, this recipe produces a soft and fragrant texture. By considering the results of the assessment, the recipe two rice recipe is deemed to be appropriate as a standard recipe. The results of the study on the third recipe (rice pindul 3) showed that Pindul rice 3 had a composition of non-savory red rice filled with anchovies chili. The combination of brown rice and anchovy chili is considered not suitable when viewed from the aspect of taste. Besides, Pindul rice 3 is considered to have a hard texture, spicy fla vor, and too large portions. Thus, Pindul rice 3 is not suitable if used as a standard recipe. Other findings, Pindul rice 4 has characteristics almost similar to white rice in general. So this recipe gives the impression there is no innovation from the recipe in general because it is considered the same as white rice. Therefore, Pindul rice 4 recipe is deemed not suitable if it will be used as a standard recipe for culina ry cave tourism.

\section{Construction Technology}

The intended technology constructs are standard processing techniques concerning tools, fireplaces, time, final results, and presentation. This is intended to maintain the quality of the product from time to time, or what is known as the production management of Pindul rice products.

\section{Food Business Constructions}

The food business that will be developed is to develop existing food businesses. This means that food businesses that are already underway are being developed further for the better, the application of sanitation and hygiene, and an attractive presentation. Culinary development efforts by combining the views of the community with suggestions from researchers then formulated and obtained the right design as a food business construct. The goal is to standardize and facilitate adoption by culinary entrepreneurs, especially local mothers' groups.

\section{DISCUSSION}

\section{Description of Location of Gunungkidul Regency}

Gunungkidul Regency is one of the districts in the Yogyakarta Special Region Province. As the largest regency in the province of Yogyakarta, GunungKidul Regency has enormous natural tourism potential to be preserved and used for the welfare of the people. Most of the regencies located in the south of Yogyakarta are highlands. Gunungkidul Regency is located between $110^{\circ} 21-110^{\circ} 50$ East Longitude and $7^{\circ}$ 46 '- $8^{\circ} 09$ South Latitude. The North is bordered by Klaten Regency and Sukoharjo Regency, Central Java Province, the South is bordered by the Indonesian Ocean, and the West is bordered by Bantul Regency and Sleman Regency, and in the East it borders Wonogiri Regency, Central Java Province. Gunungkidul Regency has an area of approximately $941,485.36 \mathrm{Km}$ or $\pm 46.63 \%$ and the total area of Yogyakarta .

Pindul cave is a tourist attraction which is located in Bejiharjo sub-district pindul cave is a tourist attraction which is an attraction from every direction. In addition to natural tourism, the Pindul cave also provides culinary tours which have become a typical icon of the area. Many tourists are interested in visiting Pindul cave. Access is easy to reach and prices are still relatively cheap so that many tourists visit.Most of the tourists will visit and visit on a trip. The type of tourism that is mostly carried out during their stay is community-based tourism, as well as sun. Findings useful for organizations working with volunteers to include in their programs (Carvache-Franco et al., 2019). 


\section{Pindul Rice Development}

The development of rice is more about empowering the potential resources of the culinary business so that it grows into a more advanced culinary business, easier to control products and services according to predetermined standards. The patterns chosen are: emphasizing the learning process, interactive participation, treating culinary business groups as partnerships and giving a big role to change and encouraging the emergence of creative ideas for culinary development based on local food into superior culinary support for tourism.

Through trials in the Laboratory of Culinary Education, Universitas Negeri Yogyakarta found recipes that were not much different from the initial construct. When testing products in the field, get advice in the form of a) Pindul Rice Products are excellent, and portions need to be adjusted to prices and consumers. b) It has been mutually agreed between researchers and food businesses that the superior product of rice is savory white rice mixed with grated cassava, wrapped in leaves and burned. c) flattened rice menu Pindul, namely: rice pindul served with side dishes in the form of tilapia, catfish, and chicken with fried or grilled techniques, supplemented with sambal and raw vegetables. d) Pindul Rice Products have been tested with limited consumers. Sensory test results and customer satisfaction tests can be seen in Table 2 . Based on sensory test results, it is known that the characteristics of rice pindul in terms of color has an average of 3.41. Pindul rice is considered to have met the criteria of respondents in terms of color. In terms of flavor, an average of 3.88 was obtained, which means that the respondent could accept and like boiled rice from its flavor. Texture gained an average of 3.06.

The taste of pindul rice two (recipe 2) was very favored by respondents, which were indicated by the average obtained at 4 . O verall, the average was 3.94. It can be concluded that pindul rice can be accepted and liked by respondents in terms of sensory. That is because Gunung Kidul District has six food crop commodities, namely rice, cassava, corn, beans, and soybeans (Figure 5). Of the six products, cassava ranks third with 45,350 hectares, and almost all regions have yields of cassava.

Table2. Sensory test results for Pindul rice 2 (Data source: Primary data)

\begin{tabular}{|c|c|c|}
\hline Characteristics & Mean & Note \\
\hline Color & 3.41 & Like \\
\hline Flavor & 3.88 & Like \\
\hline Texture & 3.06 & Like \\
\hline Taste & 4 & Very Liked \\
\hline Total & 3.94 & Like \\
\hline
\end{tabular}

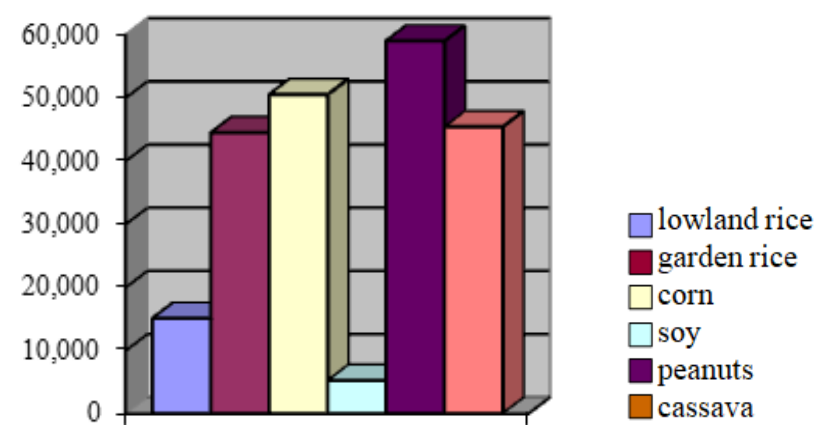

Figure 3. Diagram of Harvest Area in Food Crops in GunungKidul District, 2019 (Source: Gunung Kidul Central Bureau of Statistics, 2019)

Table 3. Test results for preference for pindul rice and Tilapia (Data source:Primary data)

\begin{tabular}{|l|c|c|}
\hline Characteristics & Mean & Note \\
\hline Color & 2 & Dislike \\
\hline Taste & 2.75 & Dislike \\
\hline Texture & 3.5 & Like \\
\hline Flavor & 3.5 & Like \\
\hline
\end{tabular}

Table 4. Test results for preference for Pindul rice and catfish

\begin{tabular}{|l|c|c|}
\hline Characteristics & Mean & Note \\
\hline Color & 3 & Like \\
\hline Taste & 2.88 & Dislike \\
\hline Texture & 2.67 & Dislike \\
\hline Flavor & 2.83 & Dislike \\
\hline
\end{tabular}

Sensory test results and customer satisfaction are supported by a favorite test on a side dish that is tilapia with fried or grilled techniques equipped with raw vegetables, and chili sauce is presented in the Table 3.

Preference test on tilapia as a companion menu for rice spinners can be seen that the characteristics of tilapia in terms of color have a mean of 2. Tilapia is considered by respondents not to meet the criteria to be liked. The taste aspect has an average of 2.75. Meanwhile, the Aspect of texture and aroma have the highest rating acquisition of 3.5. This is one proof that the pattern of fish consumption in DIY is still in the low category. Based on data from the Department of Maritime Affairs and Fisheries, Indonesia only consumes fish as much as 50.49 kilograms $(\mathrm{kg})$ per capita per year from the target of $54 \mathrm{~kg}$. Whereas in the Yogyakarta area, in 2019, the level of fish consumption is only $24.05 \mathrm{~kg}$ per capita per year. Compared to Japan, the level of fish consumption is $100 \mathrm{~kg}$ per capita per year. The level of fish consumption in Indonesia still lags far below other countries that have small fisheries resources. Nations in Asia that consume more fish than other nations that have an extreme level of work ethic, as shown by Japan and South Korea, are always showing their innovations in various fields (Djunaidah, 2017). Therefore, a breakthrough is needed to support government programs to increase fish consumption.

Preference test, catfish, is considered to have met the criteria in terms of color as a complementary menu of pindul rice. This is proven by an average gain of 3. But in terms of taste, texture, and aroma with each average of 2.88, 2.67, and 2.83 were assessed by respondents as not being able to meet the criteria to be liked (Table 4). Preference test results, it can be seen that the color aspect has an average value of 2.88 , megona, or vegetable salad assessed by respondents as not fulfilling the criteria as a complementary menu of pandul rice. The aspect of taste was assessed by respondents not yet fulfilling with an average acquisition of 2.5. Meanwhile, the aspect of texture and flavor each had an average acquisition of 2.88. This value also implies the texture and flavor of megana are not preferred (Table 5).

Table 5. Test results for favorite pindul rice and vegetable salad (megana) Table 6. Test results for preference for pindul rice and chicken (Data source:Primary data)

\begin{tabular}{|l|c|c|}
\hline Characteristics & Mean & Note \\
\hline Color & 2.88 & Dislike \\
\hline Taste & 2.5 & Dislike \\
\hline Texture & 2.88 & Dislike \\
\hline Flavor & 2.88 & Dislike \\
\hline
\end{tabular}

\begin{tabular}{|l|c|c|}
\hline Characteristics & Mean & Note \\
\hline Color & 2.75 & Dislike \\
\hline Taste & 3.25 & Like \\
\hline Texture & 3.25 & Like \\
\hline Flavor & 3.25 & Like \\
\hline
\end{tabular}

Preference test results, chicken dishes preferred by respondents as a complementary menu of pindul rice. This is evidenced by the average value of aspects of aroma, texture, and taste of 3.25 each. And 2.75 from the color aspect (Table 6). The side dish favorite test as a complementary menu of pindul rice can be seen that the characteristics of chicken are considered to be more preferred by consumers, this is indicated by the aspect of taste, texture and flavor preferred by an average of 3.25. Meanwhile, fish dishes are preferred from two aspects namely texture and flavor with an average of 3.5 each. Catfish dishes is only preferred in the average color aspect 3. While megana (vegetable salad) is less liked by consumers. Sensory test and preference test are supported by consumer satisfaction test which can be seen in Table 7 . 
Table 7. The results of customer satisfaction tests on the pindul rice (Data source: Primary data)

\begin{tabular}{|l|l|c|c|c|c|}
\hline No. & Aspect & Mean & Max score & Achievement (\%) & Rank \\
\hline 1. & Taste & 4.47 & 5 & 89.41 & 1 \\
\hline 2. & Colour & 4.24 & 5 & 84.71 & 2 \\
\hline 3. & Flavor & 4.12 & 5 & 82.35 & 4 \\
\hline 4. & Texture & 4.47 & 5 & 89.41 & 1 \\
\hline 5. & Form/design & 4.12 & 5 & 82.35 & 4 \\
\hline 6. & Portion & 3.88 & 5 & 77.65 & 3 \\
\hline 7. & Cooked level & 4.18 & 5 & 83.53 & 4 \\
\hline 8. & Packaging & 4.12 & 5 & 82.35 & 5 \\
\hline 9. & Deliciousness & 4.06 & 5 & 81.18 & 5 \\
\hline 10. & Price match & 4.06 & 5 & 81.18 & \\
\hline & Total & 41.71 & 50 & $83.41 \%$ & \\
\hline
\end{tabular}

Consumer satisfaction with pindul rice has reached $83.41 \%$. Based on the achievement ranking of each item of a statement submitted, the first rank was achieved in the aspects of food flavor and food texture. Then sequentially continued with food color, cooked level, form/design, packaging. In the last rank, the elements of deliciousness and suitability of prices with food quality.

\section{CONCLUSION}

This study concludes that consumers prefer pindul rice made from savory white rice mixed with grated cassava, wrapped in leaves, and burned. The rice is rice that can be used as one of the culinary icons of Pindul cave tourism. The impact is that the tourism sector in Gunungkidul, a district of Indonesia, is increasingly known not only for its tourist attractions but also for its local culinary specialties. Culinary businesses very easily develop the results of the research because local food is plentiful, inexpensive, and easily processed. Furthermore, it will also increase the selling price of cassava for local people. Suggestions for future research include 1) the need to standardize processes to ensure consistency of product and service quality; 2) the need for sanitation hygiene training, marketing, business management, and bookkeeping to strengthen the business base of local communities.

\section{REFERENCE}

Bianchi, C. (2017). Exploring Urban Consumers' Attitudes and Intentions to Purchase Local Food in Chile. Journal of Food Products Marketing, 23(5), 553569. https://doi.org/10.1080/10454446.2015.1048021

Björk, P., \& Kauppinen-Räisänen, H. (2014). Culinary-gastronomic tourism - a search for local food experiences. Nutrition and Food Science, 44(4), 294309. https://doi.org/10.1108/NFS-12-2013-0142

Carvache-Franco, M., Carvache-Franco, W., Contreras-Moscol, D., Andrade-Alcivar, L., \& Carvache-Franco, O. (2019). Motivations and satisfaction of volunteer tourism for the development of a destination. GeoJournal of Tourism and Geosites, 26(3), 714-725. https://doi.org/10.30892/gtg.26303-391

Choe, J.Y., \& Kim, S. (2018). Effects of tourists' local food consumption value on attitude, food destination image, and behavioral intention. International Journal of Hospitality Management, 71, 1-10. https://doi.org/10.1016/j.ijhm.2017.11.007

Djunaidah, I.S. (2017). Tingkat Konsumsi Ikan di Indonesia: Ironi di Negeri Bahari. Jurnal Penyuluhan Peri Kanan Dan Kelautan, 11(1), 12-24.

Grunert, K.G., \& Aachmann, K. (2016). Consumer reactions to the use of EU quality labels on food products: Areview of the literature. Food Control, 59, 178-187. https://doi.org/10.1016/j.foodcont.2015.05.021

Hamidah, S., \& Komariah, K. (2013). Resep dan menu. Yogyakarta: Deepublish.

Karim, S.A., Chi, C.G., \& Chi, C.G. (2017). Culinary Tourism as a Destination Attraction : An Empirical Examination of Destinations' Food Image Culinary Tourism as a Destination Attraction : An Empirical Examination of Destinations'. 8623, October. https://doi.org/10.1080/19368623.2010.493064

Kim, Y.G., \& Eves, A. (2012). Construction and validation of a scale to measure tourist motivation to consume local food. Tourism Management, 33(6), 1458-1467. https://doi.org/10.1016/j.tourman.2012.01.015

Kim, Y.G., Eves, A., \& Scarles, C. (2009). International Journal of Hospitality Management Building a model of local food consumption on trips and holidays: A grounded theory approach, 28, 423-431. https://doi.org/10.1016/j.ijhm.2008.11.005

Mahfud, T., Mulyani, Y., Indartono, S., \& Setyawati, R. (2018). Community-based tourism development: Foodies community strategy to culinary tourism development in Balikpapan-Indonesia. Journal of Tourism and Management Research, 3(2), 274-289.

Mahfud, T., Pardjono, \& Lastariwati, B. (2019). Chef's competency as a key element in food tourism success: A literature review. Geojournal of Tourism and Geosites, 26(3), 1057-1071. https://doi.org/10.30892/gtg.26329-417

Mak, A.H.N., Lumbers, M., Eves, A., \& Chang, R.C.Y. (2012). International Journal of Hospitality Management Factors influencing tourist food consumption. International Journal of Hospitality Management, 31(3), 928-936. https://doi.org/10.1016/j.ijhm.2011.10.012

Mirosa, M., \& Lawson, R. (2012). Revealing the lifestyles of local food consumers. British Food Journal, 114(6), 816-825. https://doi.org/10.1108/00070701211234345

Natalia, M.D. (2015). Ketersediaan melimpah: Ubi kayu potensi pangan lokal. Retrieved September 11, 2020. http://www.harianjogja.com/baca/2016/04/06/ kemiskinan-jogja-diy-provinsi-termiskin-di-jawa-707970

Nelson, V. (2016). Peru's image as a culinary destination. 3631(March). https://doi.org/10.1080/08873631.2016.1153269

Richey, R.C., \& Klein, J.D. (2009). Design and development research. Marwah. NJ: Lawrence Erlbaum Associates, Publishers.

Ritchie, J.R., \& Tung, V.W. (2011). Exploring the essence of memorable tourism experiences. Annals of Tourism Research, 38, 1367-1386. https://doi: 10.1016/j.annals.2011.03.009

Sam, A. (2015). TOP 2015 Consumer Trends. Asia Pasific Food Industry, 59.

Silkes, C. A., Cai, L. A., \& Lehto, X. Y. (2013). Marketing to the culinary tourist. Journal of Travel \& Tourism Marketing, 30(4), 335-349. https://doi.org/10. $1080 / 10548408.2013 .784151$

Soeroso, A., \& Susilo, Y.S. (2014). Traditional Indonesian Gastronomy as a Cultural Tourism Attraction. Journal of Applied Economics in Developing Countries, 45-59.

Sthapit, E., Björk, P., \& Coudounaris, D.N. (2017). Emotions elicited by local food consumption, memories, place attachment and behavioural intentions. Anatolia, 28(3), 363-380. https://doi.org/10.1080/13032917.2017.1322111

Sukmadinata, N.S. (2008). Educational Research Methods. Bandung: PT Remaja Rosdakarya.

Yusoff, N. (2019). Visualization of Malay Traditional Food: Emotional Expression of the Immigrants in Malaysia. 26(3), 905-915.

Zainal, A., Nizan, A., \& Nizam, M. (2010). Malaysian gastronomy routes as a tourist. [Malaysian gastronomy routes as a tourist], 15-24.

Zhang, T., Chen, J., \& Hu, B. (2019). Authenticity, quality, and loyalty: Local food and sustainable tourism experience. Sustainability (Switzerland), 11(12), 1-18. https://doi.org/10.3390/su10023437

http://bappeda.gunungkidulkab.go.id/peta-administrasi-kabupaten-gunungkidul/, accessed 08.09.2020.

https://docplayer.info/68213415-Deskripsi-wilayah-kabupaten-gunungkidul.html, accessed 12.09.2020.

https://gunungkidulkab.bps.go.id/publication/2020/03/04/0ba2275e838affcc6d2eb6c9/laporan-kinerja-badan-pusat-statistik-kabupaten-gunungkidul-tahun-2019. $\mathrm{html}$, accessed 12.09.2020 